УДК $626.81 / 84 ; 330.1 ; 330.8$

DOI https://doi.org/10.32848/agrar.innov.2021.8.7

\title{
ПРОЗОРИЙ ПІДХІД ДО ФОРМУВАННЯ ВАРТОСТІ ПОСЛУГ ІЗ ПОДАЧІ ВОДИ - ОДИН ІЗ НАПРЯМІВ РЕАЛІЗАЦІЇ СТРАТЕГІЇ ЗРОШЕННЯ ТА ДРЕНАЖУ В УКРАЇНІ НА ПЕРІОД ДО 2030 РОКУ
}

\author{
кОЗЛЕНкО Є.В. - кандидат сільськогосподарських наук, докторант \\ https://orcid.org/0000-0003-3001-8220 \\ Інститут зрошуваного землеробства Національної академії аграрних наук України \\ МОРОЗОВ О.В. - доктор сільськогосподарських наук, професор \\ https://orcid.org/0000-0002-5617-0813 \\ Херсонський державний аграрно-економічний університет \\ МОРОЗОВ В.В. - кандидат сільськогосподарських наук, професор \\ https://orcid.org/0000-0002-2594-883X \\ Херсонський державний аграрно-економічний університет
}

Постановка проблеми. Стратегією зрошення та дренажу в Україні на період до 2030 року, схваленою розпорядженням Кабінету Міністрів України від 14 серпня 2019 р. № 688-р. (далі - Стратегія) визначено галузеві проблеми, що потребують розв'язання: неврегульованість питань, які визначають умови та можливості залучення до управління та експлуатації водокористувачів як основи переведення зрошення на самофінансування; практично повна відстороненість водокористувачів від управління та формування тарифів на послуги з подачі води, недостатній рівень фінансування через відсутність коштів у державному бюджеті [1].

Метою Стратегії $є$ визначення стратегічних напрямів державної політики щодо зрошення і дренажу, забезпечення сталого екологічно збалансованого розвитку землеробства в Україні. Серед визначених шляхів досягнення Стратегії, також відображених у відповідному Плані заходів із реалізації Стратегії зрошення та дренажу в Україні на період до 2030 року, який затверджено розпорядженням Кабінету Міністрів України від 21 жовтня 2020 р. № 1567-р. (далі - План заходів), $€$ такі: відновлення і збільшення площ зрошуваних земель; поліпшення якості надання послуг із зрошення, прозорості формування тарифів; підтримка наукових досліджень у цьому напрямку [1; 2].

Одним із основних завдань, які мають бути вирішені протягом другого етапу реалізації Стратегії (2021-2024 роки), є впровадження прозорої та соціально прийнятної системи формування тарифів у практику надання послуг зі зрошення [1].

Виходячи 3 аналізу зазначених проблем, шляхів та завдань, питання прозорості механізму формування вартості послуг із подачі води є дуже актуальним і потребує наукового вивчення.

Аналіз останніх досліджень і публікацій. Технікоекономічні показники функціонування зрошувальних систем і проблеми фрормування вартості послуг із подачі води досліджували науковці Інституту зрошуваного землеробства НААН Вожегова Р.А., Грановська Л.М., Миронова Л.М., Писаренко П.В., Вердиш М.В. [3; 4; 5], науковці Інституту водних проблем і меліорації НААН Ромащенко М.І., Ковальчук П.І., Михальська Т.О., Матяш Т.В., Шевчук С.А., Волошин М.М., Пендак Н.В.,
Задорожний А.І., Ковальчук В.П., Яцюк М.В., Жовтоног О.І., Дехтяр О.О., Сайдак Р.В., Брюзгіна Н.Д., Антонюк А.В. [6; 7; 8] та інші.

Результати аналізу існуючого стану зрошення в Україні та в Південному регіоні дають підставу стверджувати таке:

- у Південному регіоні України існує створена за радянських часів мережа магістральних та розподільчих каналів із відповідним насосно-силовим обладнанням та регульованими спорудами, проєктні потужності якої значно перевищують її використання, тому ефективність експлуатації зрошувальних систем може бути підвищена за умови відновлення площ зрошення [14];

- технічний стан каналів, головних насосних станцій перекачування та підкачування, а також регульованих споруд суттєво знижує проєктні можливості існуючих зрошувальних систем унаслідок значних (до 40\%) втрат води на фрільтрацію, високих питомих витрат на електроенергію, що використовується на подачу води, внаслідок низьких (порівняно з новітніми типами) коефіцієнтів корисної дії (ККД) насосно-силового обладнання [14];

- існуюча система оплати електроенергії, яку використовують для подачі води на зрошення, потребує вдосконалення [14].

Однією з ключових пропозицій $є$ те, що тарифи на послуги з подачі води на зрошення мають формуватися за участю всіх зацікавлених сторін, що можна здійснити лише за умови прозорої системи формування тарифрів [5; 7].

Науковцями виділяється одна з проблем - відсутність участі водокористувачів у формуванні ціни на послуги з подачі води [7].

Діючими законодавчими актами, що регулюють процес надання і фрормування вартості послуг із подачі води та застосовуються водогосподарськими організаціями, $€$ Постанова Кабінету Міністрів України від 26 жовтня 2011 р. № 1101 «Про затвердження переліку платних послуг, які надаються бюджетними установами, що належать до сфери управління Державного агентства водних ресурсів України» та Наказ Міністерства екології та природних ресурсів України, Міністерства економічного розвитку і торгівлі України, Міністерства фрінансів України «Порядок визначення вартості та надання 
платних послуг бюджетними установами, що належать до сфери управління Держводагентства України», № 44/1561/1130 від 25.12.2013 [9; 10].

Мета дослідження - визначення шляхів прозорого підходу до фрормування вартості послуг із подачі води, що $є$ одним із напрямів реалізації Стратегії зрошення та дренажу в Україні на період до 2030 року, та виконання прогнозних розрахунків вартості послуг із подачі води за різних варіантів фрінансування і площ зрошуваних земель.

Матеріали та методика досліджень. У дослідженні використані матеріали Управління каналів Інгулецької зрошувальної системи (нині - Управління каналів річки Інгулець), Інституту зрошуваного землеробства НААН, проблемної науково-дослідної лабораторії еколого-меліоративного моніторингу агроекосистем сухостепової зони імені професора Д.Г. Шапошникова Херсонського ДАУ, матеріали власних досліджень авторів та інші [4] Методами дослідження є системний підхід і системний аналіз, узагальнення, порівняння, зворотній зв'язок.

Результати досліджень. Одним із завдань Стратегії $€$ впровадження прозорої та соціально прийнятної системи формування тарифів у практику надання послуг із зрошення [1]

Калькуляція вартості послуг із подачі води та загальний розрахунок, на підставі якого вона складається та нині застосовується водогосподарськими організаціями Держводагентства України за формування вартості послуг із подачі (забору) води, є документами, що відображають формування вартості послуг, але зазвичай вищезазначені документи складно назвати прозорими, тому що в них важко швидко розібратися без додаткових документів.

3 метою досягнення прозорості пропонується процес формування вартості послуг із подачі води починати з формування технологічної карти надання послуги з подачі води на зрошення, тобто всього річного виробничого процесу водогосподарської організації (організації водокористувачів або інших формувань, які надають послуги з подачі води).

Технологічні карти застосовують у різних областях та видах економічної діяльності. Враховуючи, що вони відіграють важливу роль не лише в технологічному процесі, але і в інших сферах діяльності підприємств, застосування технологічних карт уже вийшло за межі окремих технологічних процесів і поширилося в багатьох сферах економічної діяльності. Термін «технологічна карта» в різних законодавчо-нормативних джерелах має дещо відмінне визначення залежно від сфрери застосування [11]. Але під час аналізу цього питання можна визначити, що технологічна карта - документ (інструкція, письмовий опис), який установлює перелік та послідовність технологічних операцій, процедуру з організації робіт, порядок виконання робіт тощо, відображаючи необхідні для виконання процесу ресурси, матеріали й витрати, тобто комплекс параметрів, що характеризують технічний та організаційний бік виробничого процесу.

Галузі застосування технологічних карт дуже різноманітні: будівництво, машинобудування, сільське господарство, адміністративні послуги, сфера освіти (навчальний процес), лісове господарство, податкове планування та інші [11]. Нічого не заважає застосувати технологічні карти під час формування та відображення вартості послуг із подачі води на зрошення.

Технологічна карта послуги з подачі води на зрошення повинна чітко та прозоро відображати всі виробничі процеси, що відбуваються упродовж річного циклу функціонування водогосподарської організації. Отже, головний процес - подача води, в якому левову частку займають витрати на оплату електроенергії, тобто головна стаття витрат - це витрати на електроенергію, що використовується Головною насосною станцією для подачі води. Технологічними операціями з пропуску води $\epsilon$ такі: механізоване очищення каналів від водної рослинності шляхом тралення, роботи екскаваторів тощо; роботи з виконання контрольних замірів; цикл підготовчих робіт, який виконується в ремонтний період (листопад - березень), доглядові та інші роботи. Видатки на заробітну плату розраховуються згідно зі штатним розписом, який, у свою чергу, складається згідно з нормативами чисельності працівників та посадових окладів, урегульованих також законодавством.

Технологічна карта послуги з подачі води на зрошення повинна стати саме тим публічним документом, який об'єктивно відображає всі основні виробничі процеси та витрати водогосподарської організації, необхідні для надання якісної послуги з подачі води, тобто визначає потребу у фінансуванні, нестачу коштів і всі витрати, закладені в розрахунки вартості послуг із подачі води. Технологічна карта послуги з подачі води на зрошення відображає технологію, алгоритм процесу, етапи виконання виробничих операцій та відповідні витрати, необхідні для виконання послуги.

Технологічна карта послуги з подачі води на зрошення може складатись у вигляді таблиці, але більш наглядно та прозоро, на нашу думку, технологічну карту послуги з подачі води можна показати за допомогою інтелект-карти (англ. mind map). В українських перекладах термін може звучати по-різному - «карти розуму», «карти пам'яті», «ментальні карти». Інтелекткарти - це зручна та ефрективна техніка візуалізації мислення й альтернативного запису, це спосіб зображення процесу загального системного мислення за допомогою схем, який також може застосовуватися як зручна техніка альтернативного запису. Інтелект-карти нині активно використовують експерти з розвитку різних напрямів, їх можна застосовувати практично для вирішення будь-яких задач [12; 13]. Зокрема, пропонується застосовувати інтелект-карти задля створення наглядного прозорого відображення процесу формування вартості послуг із подачі води.

Нами запропоновано загальний принцип цього процесу. Повна, більш детальна технологічна карта складається в кожній водогосподарській організації із урахуванням своїх технологічних і технічних особливостей, але загальні засади для всіх єдині. Вказана технологічна карта формується на основі річних планів виробничих підрозділів і служб, які ретельно розглядаються та перевіряються виробничим відділом, усіма відділами 
та головними спеціалістами під головуванням заступника начальника, що відповідає за управління процесом формування вартості послуг, концентруючись у головного економіста для складання на її основі розрахунку вартості послуг і відповідних калькуляцій.

Нами виконано розрахунки вартості послуг із подачі води на прикладі Інгулецької зрошувальної системи (I3C). Розрахунки виконано в таких чотирьох варіантах формування вартості послуг із подачі води на зрошення:

I варіант - фрактичний за існуючої площі поливу, тобто з урахуванням частки бюджетного фрінансування, нестача якого компенсується коштами, отриманими від надання послуг із подачі води (табл. 1, 2).

У фрактичному розрахунку за існуючої площі поливу не вся нестача коштів урахована у витратах під час розрахунку вартості послуг, тому що за врахування всієї нестачі велика вірогідність того, що вартість послуг буде соціально неприйнятною для сільськогосподарських товаровиробників;

II варіант установлений також із урахуванням частки бюджетного фінансування, нестача якого компенсується коштами, отриманими від надання послуг із подачі води, але за відновлення проєктної площі поливу. Береться до уваги, що в останні роки на Інгулецькій зро- шувальній системі зрошується в середньому близько 20 тисяч гектарів. Наявність зрошувальних земель на Інгулецькій зрошувальній системі - 60 тисяч гектарів. Враховуючи, що за відновлення поливних площ до проєктного показника площа поливу збільшиться утричі порівняно з нинішньою, в розрахунках у разі відновлення площі поливу водопостачання також збільшено утричі порівняно з фактичним (табл. 1, 3);

III варіант розрахований у разі відновлення проєктної площі поливу та за повного самофінансування (відсутності бюджетного фрінансування), що передбачено Стратегією зрошення та дренажу в Україні на період до 2030 року (табл. 1, 4);

IV варіант розрахований у разі відновлення проєктної площі поливу та за повного самофрінансування (відсутності бюджетного фрінансування) зі зменшенням енергоспоживання і непродуктивних втрат води (на 5,0\%) (табл. 1, 5).

Розрахунки показали, що в разі відновлення площ зрошення до проєктного рівня згідно зі Стратегією зрошення та дренажу в Україні на період до 2030 року на I3C (варіант II) вартість послуг із подачі $1 \mathrm{~m}^{3}$ води знизиться на 23,02\%, тобто можна досягти здешевлення вартості послуг із забору води на полив завдяки розпо-

Розрахунок потреби коштів на електроенергію для перекачування води ГНС Інгулецької зрошувальної системи та вартості послуг, пов'язаних із забором води (в частині сплати за електроенергію)

\begin{tabular}{|c|c|c|c|c|c|}
\hline $\begin{array}{l}\text { № } \\
\Pi / n\end{array}$ & Варіант розрахунку & $\begin{array}{c}\text { I варіант. } \\
\text { Фактичний за } \\
\text { існуючої площі } \\
\text { поливу }\end{array}$ & $\begin{array}{l}\text { II варіант. 3а } \\
\text { відновлення } \\
\text { проєктної } \\
\text { площі поливу }\end{array}$ & $\begin{array}{c}\text { III варіант. 3а } \\
\text { відновлення } \\
\text { проєктної площі } \\
\text { поливу та пов- } \\
\text { ному самофінан- } \\
\text { суванні (відсут- } \\
\text { ність бюджетного } \\
\text { фінансування) }\end{array}$ & $\begin{array}{c}\text { IV варіант. } \\
\text { При відновленні про- } \\
\text { ектної площі поливу } \\
\text { та повному самофінан- } \\
\text { суванні (відсутність } \\
\text { бюджетного фінансу- } \\
\text { вання) із зменшенням } \\
\text { енергоспоживання } \\
\text { і непродуктивних } \\
\text { втрат води }\end{array}$ \\
\hline 1 & $\begin{array}{l}\text { Водозабір із джерела зро- } \\
\text { шення, тис. } \text { м }^{3}\end{array}$ & 128837 & 256511 & 256511 & 256511 \\
\hline 2 & Водоподача, всього (тис. м³) & 63837 & 191511 & 191511 & 191511 \\
\hline 3 & $\begin{array}{l}\text { Втрати води з каналів на філь- } \\
\text { трацію, наповнення та випаро- } \\
\text { вування, тис. м³ }\end{array}$ & 65000 & 65000 & 65000 & 65000 \\
\hline 4 & $\begin{array}{l}\text { Норма питомих витрат елек- } \\
\text { троенергії на перекачування } \\
\text { води, кВт-год. на } 1 \text { тис. } \text { м }^{3}\end{array}$ & 219 & 219 & 219 & 208 \\
\hline 5 & $\begin{array}{l}\text { Витрати ел. енергії на перека- } \\
\text { чування води, тис. кВт-год }\end{array}$ & 28215,3 & 56175,9 & 56175,9 & 53367,1 \\
\hline 6 & Тариф, грн. за 1 кВт на годину & 2,72000 & 2,72000 & 2,72000 & 2,72000 \\
\hline 7 & $\begin{array}{l}\text { Загальна потреба коштів на } \\
\text { оплату ел. енергії для перека- } \\
\text { чування води, тис. грн. }\end{array}$ & 76745,62 & 152798,47 & 152798,47 & 145158,55 \\
\hline 8 & $\begin{array}{l}\text { Виділено коштів на оплату } \\
\text { електроенергії для перекачу- } \\
\text { вання води з держбюджету, } \\
\text { тис. грн. }\end{array}$ & 28923,10 & 28923,10 & 0 & 0 \\
\hline 9 & $\begin{array}{l}\text { Нестача коштів, яка компенсу- } \\
\text { ється за рахунок водокористу- } \\
\text { вачів, тис. грн. }\end{array}$ & 47822,52 & 123875,37 & 152798,47 & 145158,55 \\
\hline 10 & $\begin{array}{l}\text { Вартість послуг для водоко- } \\
\text { ристувачів, грн. за } 1 \text { м³ }\end{array}$ & 0,7491 & 0,6468 & 0,7979 & 0,7580 \\
\hline
\end{tabular}


Зведений розрахунок планових витрат для визначення вартості послуг із подачі води (тис. грн). I варіант - фактичний за існуючої площі поливу

\begin{tabular}{|c|c|c|c|c|c|}
\hline $\begin{array}{l}\text { № } \\
\pi / n\end{array}$ & Найменування видатків & $\begin{array}{c}\text { Розрахункова } \\
\text { потреба }\end{array}$ & $\begin{array}{c}\text { Фінансування } \\
3 \text { державного } \\
\text { бюджету } \\
\end{array}$ & $\begin{array}{l}\text { Нестача } \\
\text { коштів }\end{array}$ & $\begin{array}{c}\text { Витрати, враховані } \\
\text { за розрахунку вартості } \\
\text { послуг } \\
\end{array}$ \\
\hline \multirow{3}{*}{1} & Прямі витрати на оплату праці & 27446,828 & 20081,8 & 7365,028 & 7365,028 \\
\hline & зокрема заробітна плата & 22497,40 & 16460,4 & 6037,0 & 6037,0 \\
\hline & нарахування на заробітну плату & 4949,428 & 3621,4 & 1328,028 & 1328,028 \\
\hline 2 & Прямі матеріальні витрати & 5629,287 & 303,55 & 5325,74 & 4135,221 \\
\hline \multirow[b]{2}{*}{3} & Інші прямі витрати & 81835,58 & 29020,75 & 52814,83 & 51462,122 \\
\hline & $\begin{array}{l}\text { зокрема оплата електроенергії } \\
\text { для перекачки води }\end{array}$ & 76745,62 & 28923,1 & 47822,52 & 47822,52 \\
\hline \multirow[b]{2}{*}{4} & Загальногосподарські витрати & 18094,84 & 1152,4 & 16942,44 & 5879,125 \\
\hline & $\begin{array}{l}\text { зокрема капітальний ремонт } \\
\text { і видатки на оновлення та модер- } \\
\text { нізацію основних засобів }\end{array}$ & 13205,0 & 0 & 13205,0 & 3355,0 \\
\hline 5 & Разом витрат & 133006,533 & 50558,5 & 82448,033 & 77196,051 \\
\hline 6 & $\begin{array}{l}\text { Плановий обсяг подачі води на } \\
\text { рік, тис. м }\end{array}$ & - & - & 63837 & 63837 \\
\hline 7 & $\begin{array}{l}\text { Вартість подачі } 1 \text { м³ води } \\
\text { (без ПДВ), грн. }\end{array}$ & - & - & 1,292 & 1,078 \\
\hline 8 & ПДВ (20\%), грн. & - & - & 0,258 & 0,216 \\
\hline 9 & 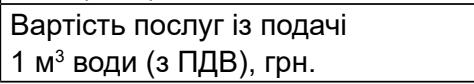 & - & - & 1,550 & 1,29 \\
\hline
\end{tabular}

Таблиця 3

Зведений розрахунок планових витрат для визначення вартості послуг із подачі води (тис. грн.) II варіант - у разі відновлення проєктної площі поливу

\begin{tabular}{|c|c|c|c|c|c|}
\hline $\begin{array}{l}\text { № } \\
\pi / n\end{array}$ & Найменування видатків & $\begin{array}{l}\text { Розрахункова } \\
\text { потреба }\end{array}$ & $\begin{array}{c}\text { Фінансування } \\
\text { з державного } \\
\text { бюджету } \\
\end{array}$ & $\begin{array}{l}\text { Нестача } \\
\text { коштів }\end{array}$ & $\begin{array}{c}\text { Витрати, враховані } \\
\text { під час розрахунку } \\
\text { вартості послуг }\end{array}$ \\
\hline \multirow{3}{*}{1} & Прямі витрати на оплату праці & 27446,828 & 20081,8 & 7365,028 & 7365,028 \\
\hline & зокрема заробітна плата & 22497,40 & 16460,4 & 6037,0 & 6037,0 \\
\hline & нарахування на заробітну плату & 4949,428 & 3621,4 & 1328,028 & 1328,028 \\
\hline 2 & Прямі матеріальні витрати & 5629,287 & 303,55 & 5325,74 & 5325,74 \\
\hline \multirow[b]{2}{*}{3} & Інші прямі витрати & 157888,43 & 29020,75 & 128867,68 & 128867,68 \\
\hline & $\begin{array}{l}\text { зокрема оплата електроенергії для } \\
\text { перекачування води }\end{array}$ & 152798,47 & 28923,1 & 123875,37 & 123875,37 \\
\hline \multirow[b]{2}{*}{4} & Загальногосподарські витрати & 18094,84 & 1152,4 & 16942,44 & 16942,44 \\
\hline & $\begin{array}{l}\text { зокрема капітальний ремонт } \\
\text { і видатки на оновлення та модерні- } \\
\text { зацію основних засобів }\end{array}$ & 13205,0 & 0 & 13205,0 & 13205,0 \\
\hline 5 & Разом витрат & 209059,383 & 50558,5 & 158500,883 & 158500,883 \\
\hline 6 & $\begin{array}{l}\text { Плановий обсяг подачі води на рік, } \\
\text { тис. м }\end{array}$ & - & - & 191511 & 191511 \\
\hline 7 & $\begin{array}{l}\text { Вартість подачі } 1 \text { м³ води } \\
\text { (без ПДВ), грн. }\end{array}$ & - & - & 0,828 & 0,828 \\
\hline 8 & ПДВ (20\%), грн. & - & - & 0,166 & 0,166 \\
\hline 9 & $\begin{array}{l}\text { Вартість послуг із подачі } 1 \text { м³ води } \\
\text { (з ПДВ), грн. }\end{array}$ & - & - & 0,993 & 0,993 \\
\hline
\end{tabular}

діленню витрат, прямо пов'язаних із наданням послуг на більший обсяг водозабору, порівняно з нині фактичним. Згідно з розрахунками, середньозважена зрошувальна норма становить 3,192 тис. м ${ }^{3}$ на га. Виходячи із цього, розрахунковий економічний ефект у разі застосування II варіанту, тобто за відновлення площ зрошення до проєктного рівня, але збереження бюджетного фінансування на рівні останніх років, становитиме 948,02 грн. на 1 га, або 56881200 грн. на весь Інгулецький зрошуваний масив (табл. 6).

Під час розгляду варіанту відновлення проєктної площі поливу та перехід зрошення на повне самофінансування, тобто за повної відсутності бюджетного фрінансування (що також передбачено Стратегією) (варіант III формування вартості послуг із подачі води на зрошення) розрахунки показали, що повинно відбутися під- 
Зведений розрахунок планових витрат для визначення вартості послуг із подачі води (тис. грн.) III варіант - у разі відновлення проєктної площі поливу та повного самофінансування (відсутності бюджетного фінансування)

\begin{tabular}{|c|c|c|c|c|c|}
\hline $\begin{array}{l}\text { № } \\
\mathbf{n} / \mathbf{n}\end{array}$ & Найменування видатків & $\begin{array}{l}\text { Розрахункова } \\
\text { потреба }\end{array}$ & $\begin{array}{c}\text { Фінансування } \\
3 \text { державного } \\
\text { бюджету }\end{array}$ & $\begin{array}{l}\text { Нестача } \\
\text { коштів }\end{array}$ & $\begin{array}{c}\text { Витрати, враховані } \\
\text { під час розрахунку } \\
\text { вартості послуг }\end{array}$ \\
\hline \multirow{3}{*}{1} & Прямі витрати на оплату праці & 27446,828 & 0 & 27446,828 & 27446,828 \\
\hline & зокрема заробітна плата & 22497,40 & 0 & 22497,40 & 22497,40 \\
\hline & нарахування на заробітну плату & 4949,428 & 0 & 4949,428 & 4949,428 \\
\hline 2 & Прямі матеріальні витрати & 5629,287 & 0 & 5629,287 & 5629,287 \\
\hline \multirow[b]{2}{*}{3} & Інші прямі витрати & 157888,43 & 0 & 157888,43 & 157888,43 \\
\hline & $\begin{array}{l}\text { зокрема оплата електроенергії } \\
\text { для перекачування води }\end{array}$ & 152798,47 & 0 & 152798,47 & 152798,47 \\
\hline \multirow[b]{2}{*}{4} & Загальногосподарські витрати & 18094,84 & 0 & 18094,84 & 18094,84 \\
\hline & $\begin{array}{l}\text { Зокрема капітальний ремонт } \\
\text { і видатки на оновлення та модер- } \\
\text { нізацію основних засобів }\end{array}$ & 13205,0 & 0 & 13205,0 & 13205,0 \\
\hline 5 & Разом витрат & 209059,383 & 0 & 209059,383 & 209059,383 \\
\hline 6 & $\begin{array}{l}\text { Плановий обсяг подачі води на рік, } \\
\text { тис. м }\end{array}$ & - & - & 191511 & 191511 \\
\hline 7 & $\begin{array}{l}\text { Вартість подачі } 1 \text { м³ води } \\
\text { (без ПДВ), грн }\end{array}$ & - & - & 1,092 & 1,092 \\
\hline 8 & ПДВ $(20 \%)$, грн. & - & - & 0,218 & 0,218 \\
\hline 9 & $\begin{array}{l}\text { Вартість послуг із подачі } 1 \text { м³ води } \\
\text { (з ПДВ), грн. }\end{array}$ & - & - & 1,310 & 1,310 \\
\hline
\end{tabular}

Таблиця 5

Зведений розрахунок планових витрат для визначення вартості послуг із подачі води (тис. грн.).

IV варіант - у разі відновлення проєктної площі поливу та повного самофінансування

(відсутності бюджетного фінансування) зі зменшенням енергоспоживання і непродуктивних втрат води

\begin{tabular}{|c|c|c|c|c|c|}
\hline $\begin{array}{l}\text { № } \\
\text { ก/ח }\end{array}$ & Найменування видатків & $\begin{array}{l}\text { Розрахункова } \\
\text { потреба }\end{array}$ & $\begin{array}{c}\text { Фінансування } \\
3 \text { державного } \\
\text { бюджету }\end{array}$ & $\begin{array}{l}\text { Нестача } \\
\text { коштів }\end{array}$ & $\begin{array}{l}\text { Витрати, враховані } \\
\text { під час розрахунку } \\
\text { вартості послуг }\end{array}$ \\
\hline \multirow{3}{*}{1} & Прямі витрати на оплату праці & 27446,828 & 0 & 27446,828 & 27446,828 \\
\hline & зокрема заробітна плата & 22497,40 & 0 & 22497,40 & 22497,40 \\
\hline & нарахування на заробітну плату & 4949,428 & 0 & 4949,428 & 4949,428 \\
\hline 2 & Прямі матеріальні витрати & 5629,287 & 0 & 5629,287 & 5629,287 \\
\hline \multirow[b]{2}{*}{3} & Інші прямі витрати & 150248,51 & 0 & 150248,51 & 150248,51 \\
\hline & $\begin{array}{l}\text { зокрема оплата електроенергії для } \\
\text { перекачування води }\end{array}$ & 145158,55 & 0 & 145158,55 & 145158,55 \\
\hline \multirow[b]{2}{*}{4} & Загальногосподарські витрати & 18094,84 & 0 & 18094,84 & 18094,84 \\
\hline & $\begin{array}{l}\text { зокрема капітальний ремонт } \\
\text { і видатки на оновлення та модерні- } \\
\text { зацію основних засобів }\end{array}$ & 13205,0 & 0 & 13205,0 & 13205,0 \\
\hline 5 & Разом витрат & 201419,463 & 0 & 201419,463 & 201419,463 \\
\hline 6 & $\begin{array}{l}\text { Плановий обсяг подачі води на рік, } \\
\text { тис. м³ }\end{array}$ & - & - & 191511 & 191511 \\
\hline 7 & $\begin{array}{l}\text { Вартість подачі } 1 \text { м³ води } \\
\text { (без ПДВ), грн. }\end{array}$ & - & - & 1,052 & 1,052 \\
\hline 8 & ПДВ (20\%), грн. & - & - & 0,210 & 0,210 \\
\hline 9 & $\begin{array}{l}\text { Вартість послуг із подачі } 1 \text { м³ води } \\
\text { (з ПДВ), грн. }\end{array}$ & - & - & 1,262 & 1,262 \\
\hline
\end{tabular}

вищення вартості послуг із подачі води на $1,55 \%$, тобто відбудеться підвищення витрат на 63,84 грн на 1 га, або 3830400 грн. на весь Інгулецький масив (табл. 6).

У варіанті відновлення проєктної площі поливу за повного самофінансування (відсутності бюджетного фрінансування) і зменшення енергоспоживання та непро- дуктивних втрат води (у розрахунках - зменшення на 5\%) (варіант IV формування вартості послуг із подачі води на зрошення) розрахунки показують, що відбуватиметься зниження вартості послуг із подачі води на $2,17 \%$, розрахунковий економічний ефект складатиме 89,38 грн. на 1 га або 5362800 грн. на весь масив (табл. 6). 
Досягнення економічного ефекту за різних варіантів розрахунків планових витрат для визначення вартості послуг із подачі води

\begin{tabular}{|c|c|c|c|c|c|}
\hline $\begin{array}{l}\text { № } \\
\pi / \Pi\end{array}$ & Варіант розрахунку & $\begin{array}{c}\text { І варіант. } \\
\text { Фактичний за } \\
\text { існуючої площі } \\
\text { поливу }\end{array}$ & $\begin{array}{c}\text { II варіант. 3a } \\
\text { відновлення } \\
\text { проєктної площі } \\
\text { поливу }\end{array}$ & $\begin{array}{c}\text { III варіант. 3а } \\
\text { відновленнія } \\
\text { проєктної площі } \\
\text { поливу та пов- } \\
\text { ному самофі- } \\
\text { нансуванні } \\
\text { (відсутність } \\
\text { бюджетного } \\
\text { фінансування) }\end{array}$ & $\begin{array}{c}\text { IV варіант. При } \\
\text { відновленні проек- } \\
\text { тної площі поливу } \\
\text { та повному самофі- } \\
\text { нансуванні (відсут- } \\
\text { ності бюджетного } \\
\text { фінансування) } \\
\text { зі зменшенням } \\
\text { енергоспоживання } \\
\text { і непродуктивних } \\
\text { втрат води }\end{array}$ \\
\hline 1 & $\begin{array}{l}\text { Водозабір із джерела зрошення, } \\
\text { тис. м³ }\end{array}$ & 128837 & 256511 & 256511 & 256511 \\
\hline 2 & Водоподача, всього (тис. м³) & 63837 & 191511 & 191511 & 191511 \\
\hline 3 & $\begin{array}{l}\text { Витрати на електроенергію для } \\
\text { перекачування води, тис. грн. }\end{array}$ & 47822,52 & 123875,37 & 152798,47 & 145158,55 \\
\hline 4 & $\begin{array}{l}\text { Вартість послуг за витратами на } \\
\text { електроенергію для перекачу- } \\
\text { вання води, грн. за } 1 \text { м }^{3}\end{array}$ & 0,7491 & 0,6468 & 0,7979 & 0,7580 \\
\hline 5 & $\begin{array}{l}\text { Різниця у вартості послуг за } \\
\text { витратами на електроенергію для } \\
\text { перекачування води, \% }\end{array}$ & - & $-13,7 \%$ & $+6,5 \%$ & $+1,2 \%$ \\
\hline 6 & Разом витрат, тис. грн. & 77196,051 & 158500,883 & 209059,383 & 201419,463 \\
\hline 7 & $\begin{array}{l}\text { Вартість послуг із подачі } 1 \text { м³ води } \\
\text { (з ПДВ), грн. }\end{array}$ & 1,290 & 0,993 & 1,310 & 1,262 \\
\hline 8 & 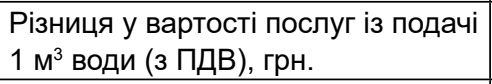 & - & $-0,297$ & $+0,020$ & $-0,028$ \\
\hline 9 & 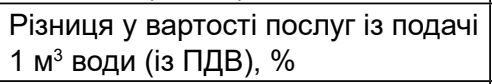 & - & $-23,02 \%$ & $+1,55 \%$ & $-2,17 \%$ \\
\hline 10 & Економічний ефект на 1 га, грн. & - & 948,02 & $-63,84$ & 89,38 \\
\hline 11 & $\begin{array}{l}\text { Економічний ефект на масиві, } \\
\text { грн. }\end{array}$ & - & 56881200 & -3830400 & 5362800 \\
\hline
\end{tabular}

Висновки. На основі вищезазначеного нами сформульовані такі висновки:

1) із метою досягнення прозорості (на виконання завдань Стратегії) запропоновано процес формування вартості послуг із подачі води на зрошення починати з формування технологічної карти послуг із подачі води на зрошення, тобто всього річного виробничого процесу водогосподарської організації (або організації водокористувачів), у котрій чітко і прозоро повинні відображатися всі виробничі процеси, що відбуваються протягом річного циклу функціонування водогосподарської організації, та відповідні витрати. Вищезазначена технологічна карта послуг із подачі води на зрошення повинна стати публічним документом, який водогосподарська організація, що надає послуги, повинна надавати за вимогою водокористувачів (або розміщати на своєму офіційному сайті). Таким способом забезпечуватиметься прозорість системи формування тарифів під час надання послуг із подачі води на зрошення та усуватиметься відстороненість водокористувачів від формування вищеназваних тарифрів;

2) розрахунки показали, що за відновлення площ зрошення до проєктного рівня згідно зі Стратегією, але за збереження бюджетного фінансування на рівні останніх років (варіант II) вартість послуг із подачі $1 \mathrm{~m}^{3}$ води знизиться на 23,02 \%, тобто можна досягти здешевлення вартості послуг із забору води на полив завдяки розподіленню витрат, прямо пов'язаних із наданням послуг на більший обсяг водозабору, ніж фактичний на цей час. Розрахунковий економічний ефект у разі застосування II варіанту становитиме 948,02 грн. на 1 га або 56881200 грн. на весь Інгулецький зрошуваний масив;

3) за умови відновлення проєктної площі поливу та переходу зрошення на повне самофрінансування, тобто за повної відсутності бюджетного фінансування (що теж передбачено Стратегією) (варіант III) розрахунки показали, що має відбутися подорожчання вартості послуг із подачі води на 1,55\%, тобто відбудеться підвищення витрат на 63,84 грн. на 1 га або 3830400 грн. на весь масив;

4) у варіанті IV - відновлення проєктної площі поливу за повного самофрінансування (відсутності бюджетного фрінансування) і зменшення енергоспоживання та непродуктивних втрат води (на 5\%) відбуватиметься зниження вартості послуг із подачі води на 2,17 \%; розрахунковий економічний ефект складатиме 89,38 грн. на 1 га або 5362800 грн. на весь масив;

5) за відновлення проєктних площ зрошуваних земель та переведення зрошення на самофрінансування (як це передбачено Стратегією зрошення та дренажу 
в Україні на період до 2030 року) вартість послуг із подачі води, згідно з розрахунками, підвищиться порівняно 3 фрактичною вартістю на цей час, тому задля отримання економічного ефекту вищезазначені заходи, передбачені Стратегією, слід виконувати тільки в комплексі із заходами щодо зменшення енергоспоживання та непродуктивних втрат води. Водночас задля досягнення прозорої системи формування вартості послуг із подачі води слід застосовувати технологічні карти послуги із подачі води.

\section{СПИСОК ВИКОРИСТАНОЇ ЛІТЕРАТУРИ:}

1. Стратегія зрошення та дренажу в Україні на період до 2030 року: схвалено розпорядженням Кабінету Міністрів України від 14.08.2019 р. № 688-p. URL: https://zakon.rada.gov.ua/laws/show/688-2019-p\#Text

2. План заходів із реалізації Стратегії зрошення та дренажу в Україні на період до 2030 року: затверджено розпорядженням Кабінету Міністрів України від 21.10.2020 р. № 1567-p. URL: https://zakon.rada. gov.ua/laws/show/1567-2020-p\#Text

3. Вожегова Р.А., Грановська Л.М., Миронова Л.М., Писаренко П.В., Вердиш М.В. Вплив вартості води на економічну ефективність виробництва аграрної продукції в зоні зрошення. Зрошуване землеробство. Херсон, 2012. № 58. С. 154-157.

4. Вожегова Р.А., Козленко Є.В., Морозов О.В., Морозов В.В. Шляхи реалізації Стратегії зрошення та дренажу в Україні на період до 2030 року на Інгулецькій зрошувальній системі. Зрошуване землеробство. Херсон, 2021. № 75. С. 10-15.

5. Грановська Л.М., Пілярська О.О. Законодавче регулювання відновлення та розвитку зрошення в Україні. Зрошуване землеробство. Херсон, 2020. № 74. C. 28-35.

6. Ромащенко М.І., Яцюк М.В., Жовтоног О.І., Дехтяр О.О., Сайдак Р.В., Матяш Т.В. Наукові засади відновлення та розвитку зрошення в Україні в сучасних умовах. Меліорація і водне господарство. 2017. № 106. С. 9-14.

7. Ромащенко М.І., Ковальчук П.І., Михальська Т.О., Матяш Т.В., Шевчук С.А., Волошин М.М., Пендак Н.В., Задорожний А.І., Ковальчук В.П. Методика формування ціни на подачу води на зрошення, промислові та комунальні потреби. Київ, 2006. 33 с.

8. Дехтяр О.О., Брюзгіна Н.Д., Антонюк А.В. Аналіз функціонування зрошувальних систем за техніко-технологічними та економічними показниками. Вісник аграрної науки. 2019. № 3 (792). С. 50-56.

9. Про затвердження переліку платних послуг, як надаються бюджетними установами, що належать до сфрери управління Державного агентства водних ресурсів. Постанова КМУ від 26.10.2011p. № 1101 https://zakon.rada.gov.ua/laws/show/1101-2011-п\#Text

10. Порядок визначення вартості та надання платних послуг бюджетними установами, що належать до сфери управління Держводагентства України. Наказ Міністерства екології та природних ресурсів України, Міністерства економічного розвитку і торгівлі України, Міністерства фрінансів України від 25.12.2013 р. № 44/1561/1130 https://zakon.rada.gov.ua/laws/show/ z0163-14\#Text

11. Оліховський В.Я. Технологічні карти та можливості їх використання у податковому плануванні. Вісник
Національного університету «Львівська політехніка». 2014. № 794. С. 295-304.

12. Сталий інноваційний розвиток: Створення інтелект-карти. [Електронний ресурс]: навч. посіб. КП। ім. Ігоря Сікорського; уклад.: Караєва Н.В. Електронні текстові дані (1 файл: 24,3 Мбайт). Київ : КПІ ім. Ігоря Сікорського, 2021. 70 с.

13. Бьюзен Т. и Б. Супермышление. Пер. С англ. Е.А. Самсонов. 2-е изд. Минск : ООО «Попурри», 2003. 304 C.

14. Концепція відновлення та розвитку зрошення у південному регіоні України. Київ : ЦП «Компринг», 2014. $28 \mathrm{c}$.

\section{References:}

1. Stratehiia zroshennia ta drenazhu v Ukraini na period do 2030 roku [Irrigation and drainage strategy in Ukraine for the period up to 2030]: skhvaleno rozporiadzhenniam Kabinetu Ministriv Ukrainy vid 14.08.2019 r. № 688-r. URL: https://zakon.rada.gov.ua/laws/show/688-2019-r \#Text [in Ukrainian].

2. Plan zakhodiv $z$ realizatsii Stratehii zroshennia ta drenazhu v Ukraini na period do 2030 roku [Action plan for the implementation of the Irrigation and Drainage Strategy in Ukraine for the period up to 2030]: zatverdzheno rozporiadzhenniam Kabinetu Ministriv Ukrainy vid 21.10.2020 r. № 1567-r. URL: https:// zakon.rada.gov.ua/laws/show/1567-2020-r\#Text [in Ukrainian].

3. Vozhehova, R.A., Hranovska, L.M., Myronova, L.M., Pysarenko, P.V., \& Verdysh, M.V. (2012). Vplyv vartosti vody na ekonomichnu efektyvnist vyrobnytstva ahrarnoi produktsii $v$ zoni zroshennia [The impact of water costs on the economic efficiency of agricultural production in the irrigation zone]. Zroshuvane zemlerobstvo Irrigated agriculture, 58, 154-157 [in Ukrainian].

4. Vozhehova, R.A., Kozlenko, Ye.V., Morozov, O.V., \& Morozov, V.V. (2021). Shliakhy realizatsii Stratehii zroshennia ta drenazhu v Ukraini na period do 2030 roku na Inhuletskii zroshuvalnii systemi [Ways to implement the Irrigation and Drainage Strategy in Ukraine for the period up to 2030 on the Ingulets irrigation system]. Zroshuvane zemlerobstvo - Irrigated agriculture, 75, 10-15 [in Ukrainian].

5. Hranovska, L.M., Piliarska, O.O. (2020). Zakonodavche rehuliuvannia vidnovlennia ta rozvytku zroshennia $v$ Ukraini [Legislative regulation of irrigation restoration and development in Ukraine]. Zroshuvane zemlerobstvo - Irrigated agriculture, 74, 28-35 [in Ukrainian].

6. Romashchenko, M.I., Yatsiuk, M.V., Zhovtonoh, O.I., Dekhtiar, O.O., Saidak, R.V. \& Matiash, T.V. (2017). Naukovi zasady vidnovlennia ta rozvytku zroshennia $v$ Ukraini $v$ suchasnykh umovakh [Scientific principles of restoration and development of irrigation in Ukraine in modern conditions]. Melioratsiia I vodne hospodarstvoLand reclamation and water management, 106, 9-14 [in Ukrainian].

7. Romashchenko, M.I., Kovalchuk, P.I., Mykhalska, T.O., Matiash, T.V., Shevchuk, S.A., Voloshyn, M.M., Pendak, N.V., Zadorozhnyi, A.I., \& Kovalchuk, V.P. (2006). Metodyka formuvannia tsiny na podachu vody na zroshennia, promyslovi ta komunalni potreby [Methods of forming the price of water supply for irrigation, industrial and municipal needs]. Kiev [in Ukrainian]. 
8. Dekhtiar, O.O., Briuzghina, N.D. \& Antoniuk, A.V. (2019). Analiz funktsionuvannia zroshuvalnykh system za tekhniko-tekhnolohichnymy ta ekonomichnymy pokaznykamy [Analysis of the functioning of irrigation systems by technical-technological and economic indicators]. Visnyk ahrarnoi nauky - Bulletin of Agricultural Science, 3 (792), 50-56 [in Ukrainian].

9. Pro zatverdzhennia pereliku platnykh posluh, yaki nadaiutsia biudzhetnymy ustanovamy, shcho nalezhat do sfery upravlinnia Derzhavnoho ahentstva vodnykh resursiv [On approval of the list of paid services provided by budgetary institutions belonging to the sphere of management of the State Agency of Water Resources]. Postanova KMU vid 26.10.2011r. № 1101 https://zakon.rada.gov.ua/laws/show/1101-2011-п\#Text [in Ukrainian].

10. Poriadok vyznachennia vartosti ta nadannia platnykh posluh biudzhetnymy ustanovamy, shcho nalezhat do sfery upravlinnia Derzhvodahentstva Ukrainy [The procedure for determining the cost and provision of paid services by budgetary institutions belonging to the sphere of management of the State Water Agency of Ukraine]. Nakaz Ministerstva ekolohii ta pryrodnykh resursiv Ukrainy, Ministerstva ekonomichnoho rozvytku i torhivli Ukrainy, Ministerstva finansiv Ukrainy vid 25.12.2013 r. № 44/1561/1130 https://zakon.rada.gov. ua/laws/show/z0163-14\#Text [in Ukrainian].

11. Olikhovskyi, V.la. (2014). Tekhnolohichni karty ta mozhlyvosti yikh vykorystannia u podatkovomu planuvanni [Technological maps and possibilities of their use in tax planning]. Visnyk Natsionalnoho universytetu «Lvivska politekhnika» - Bulletin of the National University "Lviv Polytechnic", 794, 295-304 [in Ukrainian].

12. Stalyi innovatsiinyi rozvytok: Stvorennia intelekt-karty [Sustainable innovation development: Creating an intelligence map]. [Elektronnyi resurs]: navch. posib. KPI im. Ihoria Sikorskoho; uklad.: Karaieva, N.V. (2021) Elektronni tekstovi dani (1 fail: 24,3 Mbait). Kyiv : KPI im. Ihoria Sikorskoho [in Ukrainian].

13. Biuzen, T. y B. (2003). Supermyishlenye [Superthought] / Per. S anhl. E.A. Samsonov. 2-e yzd. Mynsk : OOO «Popurry» [in Russian].

14. Kontseptsiia vidnovlennia ta rozvytku zroshennia u pivdennomu rehioni Ukrainy [The concept of restoration and development of irrigation in the southern region of Ukraine]. (2014). Kyiv : TsP «Komprynh» [in Ukrainian]

Козленко Є.В., Морозов О.В., Морозов В.В. Прозорий підхід до формування вартості послуг 3 подачі води - один із напрямів реалізації Стратегії зрошення та дренажу в Україні на період до 2030 року

Мета дослідження - визначення шляхів прозорого підходу до формування вартості послуг із подачі води, який $є$ одним із напрямів реалізації Стратегії зрошення та дренажу в Україні на період до 2030 року, та виконання прогнозних розрахунків вартості послуг із подачі води за різних варіантів фрінансування і площ зрошуваних земель. Методи: системний підхід і системний аналіз, узагальнення, порівняння, зворотній зв'язок. Результати. Із метою досягнення прозорості (на виконання завдань Стратегії зрошення та дренажу до 2030 року) запропоновано процес формування вартості послуг із подачі води на зрошення починати з формування технологічної карти послуги з подачі води на зрошення, тобто всього річного виробничого процесу водогосподарської організації (або організації водокористувачів), у котрій чітко і прозоро мають відображатись усі виробничі процеси, які відбуваються протягом річного циклу функціонування водогосподарської організації, та відповідні витрати. Вищезазначена технологічна карта послуги з подачі води на зрошення має стати публічним документом, який водогосподарська організація, що надає послуги, повинна надавати за вимогою водокористувачів (або розміщати на своєму офріційному сайті). Таким способом забезпечуватиметься прозорість системи формування тарифрів у практиці надання послуг із подачі води на зрошення та усуватиметься відстороненість водокористувачів від формування вищезазначених тарифів. Висновки. Розрахунки показали, що за відновлення проєктної площі зрошення і збереження бюджетного фрінансування на рівні останніх років розрахунковий економічний ефект становитиме 948,02 грн. на 1 га або 56881200 грн. на весь Інгулецький зрошуваний масив. У разі переходу зрошення на повне самофрінансування, згідно з розрахунками, відбудеться підвищення витрат на 63,84 грн. на 1 га або 3830400 грн. на весь масив. За тих самих умов, але за зменшення енергоспоживання та непродуктивних втрат води (на 5\%) відбуватиметься зниження вартості послуг із подачі води; розрахунковий економічний ефект складатиме 89,38 грн. на 1 га або 5362800 грн. на весь масив. У разі відновлення проєктних площ зрошуваних земель і переведення зрошення на самофінансування (як це передбачено Стратегією зрошення та дренажу в Україні на період до 2030 року) вартість послуг із подачі води, згідно з розрахунками, підвищиться порівняно з фактичною вартістю на цей час, тому для отримання економічного ефекту вищезазначені заходи, передбачені Стратегією, необхідно виконувати тільки в комплексі із заходами зі зменшення енергоспоживання і непродуктивних втрат води. Водночас для досягнення прозорої системи формування вартості послуг із подачі води слід застосувати технологічні карти послуги з подачі води.

Ключові слова: Стратегія, зрошення, вартість послуг, технологічна карта, площа поливу, економічний есрект.

Kozlenko Y.V., Morozov O.V., Morozov V.V. A transparent approach to the formation of the cost of water supply services - one of the directions of implementation of the Strategy of Irrigation and Drainage in Ukraine for the period up to 2030

Goal: To identify the ways of a transparent approach to the formation of the cost of water supply services, which is one of the directions of implementation of the Strategy of Irrigation and Drainage in Ukraine for the period up to $2030 \$$ to perform forecast calculations of the cost of water supply services for different financing options and areas of irrigated land. Methods: systemio approach and system atic data analysis, generalization, comparison and feedback. Results. In order to achieve transparency (to meet the objectives of the Strategy of Irrigation and Drainage up to 2030), the process of forming the cost of water supply services for irrigation is proposed to begin with the formation of a technological map of water supply services for irrigation, ie the entire annual production process of water management organization (or organization 
of water users), which should clearly and transparently reflect all production processes that occur during the annual cycle of operation of the water management organization and the associated costs. The above-mentioned technological map of water supply services for irrigation should become a public document, which the water management organization providing services must offer at the request of water users (or post on its official website). This will ensure the transparency of the tariff formation system in the practice of providing water supply services for irrigation and will eliminate the exclusion of water users from the formation of the above mentioned tariffs. Conclusions. The calculations show that with the restoration of the project area of irrigation and maintaining budget funding at the level of recent years, the estimated economic effect will be UAH 948,02 per 1 ha, or UAH 56,881,200 for the entire Ingulets irrigated area. In the case of the transition of irrigation to full self-financing, according to the calculations, there will be an increase in the costs by UAH 63,84 per
1 hectare, or UAH 3,830,400 for the entire array. Under the same conditions, but with a decrease in energy consumption and unproductive water losses (by 5,0\%) there will be a decrease in the cost of water supply services and the estimated economic effect will be 89,38 UAH per 1 ha or $5362800 \mathrm{UAH}$ for the entire array. That is, with the restoration of the project area of irrigated land and the transfer of irrigation to self-financing (as provided by the Strategy of Irrigation and Drainage in Ukraine up to 2030) the cost of water supply services according to the calculations will increase compared to the current one, therer fore the measures envisaged by the Strategy should be implemented only in combination with the measures to reduce energy consumption and unproductive water losses. At the same time, in order to achieve a transparent system of forming the cost of water supply services, technological maps of water supply services should be used.

Key words: strategy, irrigation, cost of services, technological map, irrigation area, economic effect. 